\title{
The relationship between Writing Anxiety and Students' Writing Performance at Wolkite University First Year English Major Students
}

\author{
Anwar Nessir Surur, Senbeta Tadesse Dengela
}

Wolkite University, College of Social Science and Humanities, English Department, Ethiopia

\begin{abstract}
This study was carried out to investigate the relationship between second language writing anxiety and students' writing performance. The study employed correlation and descriptive study design. First year English language and literature students of Wolkite University were the participants of the study and they were selected by using simple random sampling technique. Questionnaire, writing performance tests and semi-structured interview were used as data collecting instruments. These data were analyzed using Pearson's Product moment correlation, qualitative description of students' interview results and one way ANOVA. In order to identify the significance of differences between the pairs of SL writing anxiety, multiple comparisons or post hoc test was also conducted.The results revealed that there was a significant, negative correlation between SL writing anxiety and writing performance. The semi-structured interview revealed that linguistic difficulties, insufficient writing practice, fear of tests, lack of topical knowledge and low self-confidence in writing performance. The results of the questionnaire showed that there is statistically significant difference in level of anxiety among high, average and low achievers and Avoidance Behavior and Cognitive anxiety are the most common and dominant type of ESL/FL writing anxiety. The investigation results also showed that the mean differences were statistically significant between the low anxiety and average anxiety, low anxiety and high anxiety and average anxiety and high anxiety.
\end{abstract}

Keywords - Writing Anxiety, Writing Performance, correlation analysis.

\section{BACKGROUND OF THE STUDY}

Writing performance of an English learner can reflects the learner's knowledge in English language patterns through the written discourse they present (Hartono, 2012:107). As many ESL/FL researchers and ESL teachers' assertion, teaching second language writing is difficult task (Barkaoui, 2007:35). Evidence from a number of local studies (e.g. Abate, 1996; Alamirew, 2005; Yonas, 1996 \& Italo, 1999) on English performance of Ethiopian ESL/FL students' show those learners' repeated failure in English Examinations could potentially imply their incompetence to use the language when demanded. In connection with this, students' ESL/FL proficiency might be attributed to factors such as motivation anxiety (Abate, 1996) and efficacy beliefs.

Therefore, there are reasons why the second or foreign language writing performance and writing anxiety are negatively or positively correlated or related to each other in ESL/FL contexts and why the second or foreign language learners feel anxious when writing might be different and multiple.

\section{STATEMENT OF THE PROBLEM}

Many language learners found that writing as the most difficult skill to master or handle (Latiff, 2007; Kurt \& Atay, 2007). In spite of unclear investigation on the area, there was the prevalence of reluctance to write in English, the levels and sources of fear of writing on the EFL learners.

Currently, in Ethiopia education policy, students are exposed to practice writing skill in early grade level since English is taught as a subject starting from primary level and used as a medium of instruction starting from secondary schools in many parts of the country. However, some local studies revealed that the writing performances of students of Colleges and Universities were found to be below the expectation though they have learned the language from primary level to University level (Amlaku, 2013; Alamirew, 2005).

Besides this, some researchers (Abate, 1996; Melese, 2007; Dangachew 2013) also tried to find the impact of anxiety on the students' writing performance. According to these 
researchers, most of the problems were related to foreign language anxiety, foreign language writing anxiety on EFL College students' performance, impacts of EFL writing anxiety on preparatory students 'writing performance and EFL writing test anxiety on students' writing performance .For instance, Abate (1996) studied English language classroom anxiety, performance on classroom tasks and in tests at Addis Ababa University. In his finding, he indicated that learners' anxiety scores were negatively and significantly associated with their language performance and the results implied the harmful effects of anxiety and the tendency of low anxious students to perform relatively better than high anxious learners.

The things that make differ this study from previous studies were, by way of investigating the relationship of English writing anxiety and students' writing performance within particular language skill, to fill the gap seen in the previous local studies and though locally there have been many studies done in the area in different EFL skills and levels, the researcher couldn't find any relational or correlation study done in Wolkite university.

\section{OBJECTIVES OF THE STUDY}

The general objective of this study was to investigate the relationship between writing anxiety and students' writing performance of first year English major students at Wolkite University. To this end the specific objectives of the study were to:

$>$ Determine the relationship between writing anxiety and students' writing performance.

$>$ Identify the general causes of writing anxiety.

$>$ Examine whether there is statistically significant difference in level of anxiety among low, average and high achievers.

$>$ Identify the dominant type of writing anxiety the students' experience.

\section{RESEARCH METHODOLOGY}

\subsection{Research Design}

This study employed a correlation research design to correlate writing anxiety and students' writing performance. Creswell (2012:20) explained that" correlation research is associating or relating variables in a predictable pattern for one group of individuals"

This research design more focuses on examining the association or relation of one or more variables than in testing the impact of activities or materials.

\subsection{Population of the Study}

The total number of students who were selected to the study was 80 (53 males and 27 females). The participants were selected from two freshmen groups (first year English major students). The reasons for selecting this study area are: 1) the researcher of this study has been teaching in the study area, and closely experienced the complex or difficult nature of writing skill in teaching and learning process and 2) experienced teachers /instructors are assumed to be available in the study area.

\subsection{Sample and Sampling Techniques}

The participants of this study were 80 students out of 120 of English Department. Therefore, 67\% of students from the total were selected to this study. Out of 80 students who filled the questionnaire, 10 students were chosen from three levels (High-anxiety, Moderate-anxiety and Low-anxiety) for the interview, giving equal proportion (chance for each of them.

\subsection{Data Collection Instruments}

The research instruments used in this study include document, Questionnaires (for only students)-the Second Language Writing Anxiety Inventory (SLWAI), writing comprehension test and semi-structured interview.

\subsubsection{Written Descriptive task (Indices of English writing performance)}

The participants' grades on a 30-minute English composition and English writing comprehension test were both used as indices of their writing performance. In order to ensure whether there is significant difference among participants regarding to their writing performance and to investigate whether time constraint affects FL students' writing composition or not, participants were asked to write an English composition within 30 minutes in class, which administrated and evaluated by their instructor who has fiveyear experience as an ESL writing instructor. Each composition was graded on a25-point scale

\subsubsection{Semi-structured interview}

Semi- structured interview questions were prepared for 10 students out of 80 participants ( 3 from High-anxious and 3 from Moderate-anxious, and 4 from Low-anxious) and asked the students to specify the major causes of writing anxieties in which they feel anxious to write, and the difficulties they experience when they write in English.

\section{DATA ANALYSIS PROCEDURES}

The researcher selected a specific design for the study which is consistent with the objectives of the research and employed multiple procedures to collect data from the 
sample subjects in which the translated version of SLWAS was piloted on twenty students who were not the subjects of the study. These enabled the researcher to see whether the tools were practical or not. After the researcher collected the participants' information from the stream and pilot test, he asked sample students to write English composition under time constraint (30 minutes) at the beginning of an English writing class. The interview was also administered to 10 students to triangulate the data and reach at more in-depth information.

The study used descriptive correlation research design and the researcher employed Pearson Product Moment correlation coefficient to measure the relationship between writing anxiety and students' writing performance and calculated to show the relationship between two variables. Correlation analysis is used to describe the strength and direction of the linear relationship between two variables. According to Hatch and Farhady (1981; cited in Language Learning Journal of the relationship between listening anxiety and listening comprehension, 2017), there are some underlying assumptions that have to be met for Pearson correlation analysis. The assumptions are:

1 . The two variables are continuous,

2. Scores on $X$ and $Y$ are independent of each other, and

3. The relationship between $\mathrm{X}$ and $\mathrm{Y}$ is linear.

The data obtained from the writing comprehension test and SLWAI questionnaire were analyzed quantitatively by using the latest SPSS version windows 20 (Special Software called Statistical Package for Social Sciences) to obtain the levels and types of ESL writing anxiety experienced by the students, and to measure if there is a significant difference in the levels of anxiety among the freshmen.

The researcher also used one-way ANOVA to investigate whether English writing anxiety affect English writing performance or not on the performance based essay task /test and employed to determine the possible differences among the writing performances of students with low, average, and high level of anxiety.

Finally, the study used qualitative analysis of the interview in order to get detailed information about the major causes of writing anxiety.

\section{RESULTS AND DISCUSSIONS}

\subsection{Results of correlation of Writing performance and} Writing anxiety

To determine the significant relationship between second language writing anxiety and students' writing performance, the writing performance test was administered and the papers were corrected. Then after, values for the students' performance were given according to the grading system set by College of Ethiopian higher institution students' promotion. According to the College, the grading system is presented as follows:

80-84 A- 85-90 A 90-100 A+

65-69 B- 70-74 B 75-79 B+

45-49 C- 50-59 C 60-64 C+

30-39 FX 40-44 D 45-49 C-

Below $30 \mathrm{~F}$

Table.1: Frequency of the participants' writing Test performance

\begin{tabular}{|l|l|l|l|}
\hline $\mathrm{N} / \mathrm{S}$ & Grading system & Frequency & Percent \\
\hline 1 & $80-100=\mathrm{A}-, \mathrm{A}, \mathrm{A}+$ & 8 & 10 \\
\hline 2 & $65-79=\mathrm{B}-, \mathrm{B}, \mathrm{B}+$ (Range) & 34 & 42.5 \\
\hline 3 & $45-59=\mathrm{C}-\mathrm{C}, \mathrm{C}+$ (Range) & 38 & 47.5 \\
\hline 4 & Below 30=F & 0 & 0 \\
\hline \multicolumn{2}{|l|}{ Total } & 80 & 100 \\
\hline
\end{tabular}

The above Table shows that only $8(10 \%)$ of the participants or students scored A (80-100). The other 34(42.5) of the students got B (65-79). Another 38 (47.5\%) of the students scored or graded C (45-59).

The above achievement or performance grades of students revealed that almost half of the students scored $\mathrm{C}$ (47.5\%) and $34(42.5 \%)$ scored B. This indicates that most of the students had difficulty of writing and understanding writing process and its basic components.

Since the grading system set by the University contains different scales, the researcher tried to change it into 3 (three) scales for leveling the students into low, average and high achievers on the basis of their writing performance test scores. To do so, the students who got the mark 80-100 (A) in the grading system were considered as high achievers. The other group that scored 65-79 (B) in the grading system was taken as average or moderate achievers. The remaining group who earned the mark below 59 (45-59) and below 30(F) in the grading system was considered as low achievers.

Table.2: Students' classification based on performance (achievement)

\begin{tabular}{|l|l|l|l|}
\hline Scores & Levels & Frequency & Percent \\
\hline $80-100$ & High & 8 & 10 \\
\hline 65-79 & Average & 34 & 42.5 \\
\hline Below 59 & Low & 38 & 47.5 \\
\hline Total & 80 & 100 \\
\hline
\end{tabular}

From this Table, one can understand that few students $8(10 \%)$ were high achievers (scored 80-100). The others 
$34(42.5 \%)$ were average achievers (scored 65-79). The remaining almost half of the subjects or students $38(47.5 \%)$ who earned the mark below 59 were low achievers. The number of lower achievers was near to half of the total students. This means the majority of the subjects have difficulty of writing and understanding writing comprehension because of various reasons reported by the subjects.

Table.3: Distribution of the participants' L2 writing Anxiety Levels

\begin{tabular}{|l|l|l|l|}
\hline Anxiety levels & Anxiety & № of & Percent \\
\hline Low anxiety & $22-50$ & 4 & 5 \\
\hline Average anxiety & $51-65$ & 18 & 22.5 \\
\hline High anxiety & $66-110$ & 58 & 72.5 \\
\hline Total & & 80 & 100 \\
\hline
\end{tabular}

As can be seen from the Table above, the number of students experiencing high levels of anxiety $58(72.5 \%$ ) is more than the number of students with average anxiety $18(22.5 \%)$ and more than twice the number of students with low levels of L2 writing anxiety. Of the 80 students, only 4(5\%) experienced low levels of L2 writing anxiety.

In order to investigate the degree of the subjects' L2 writing anxiety, descriptive statistics of SLWAS questionnaire was conducted.

Table 4: Descriptive statistics of SLWAS questionnaire

\begin{tabular}{|l|l|l|l|l|l|}
\hline & $\mathrm{N}$ & Minimum & Maximum & Mean & $\begin{array}{l}\text { Std. } \\
\text { Deviation }\end{array}$ \\
\hline $\begin{array}{l}\text { Anxiety } \\
\text { Valid N } \\
\text { (list } \\
\text { wise) }\end{array}$ & $\begin{array}{l}80 \\
80\end{array}$ & 45 & 90 & 69.70 & 9.039 \\
\hline
\end{tabular}

The above Table shows that the mean $\mathrm{M}=69.70$ and Std. Deviation $\mathrm{SD}=9.039$. The result indicated that the subjects have experienced high writing anxiety, which reflects that during the process of writing activities, the students easily become anxious. This situation is probably associated to the emotional states of $\mathrm{L} 2$ students. In addition, writing activities are complex, need some grammatical and linguistic proficiency, so L2 students always take a heavy physiological and psychological burden and need to avoid the writing activities. In the investigation of SLWA, 48(60\%) students chose "strongly agree or agree" when answering the item "I usually do my best to avoid writing English compositions," 67(84\%) students chose "strongly agree or agree" in the item "I do my best to avoid situations in which I have to write in English ". Similarly, 41(51\%) students chose "strongly agree or agree" in the item" I feel my heart pounding when I write English compositions under time constraint." Therefore, anxiety is pervasive or manifested throughout in second language writing activities.

From the above scatter plot, there appears to be a strong, negative correlation between the two variables (writing performance test scores and writing anxiety scores) for the sample as a whole. Respondents who scored good mark (shown on the $\mathrm{Y}$ or vertical axis) experience lower level of writing anxiety (shown on the $\mathrm{X}$, or horizontal axis). On the other hand, respondents who scored less mark (shown on the $\mathrm{Y}$, or vertical axis) experience high level of writing anxiety (shown on the $\mathrm{X}$, or horizontal axis). The scatter plot indicated that when one of the variables (writing performance test score) increased, the other variable (writing anxiety score) decreased, in other words, when the writing performance test score decreased, the writing anxiety score increased.

This means there is a negative correlation between the two variables; so would be appropriate to calculate a Pearson Product-moment correlation for these two variables. 


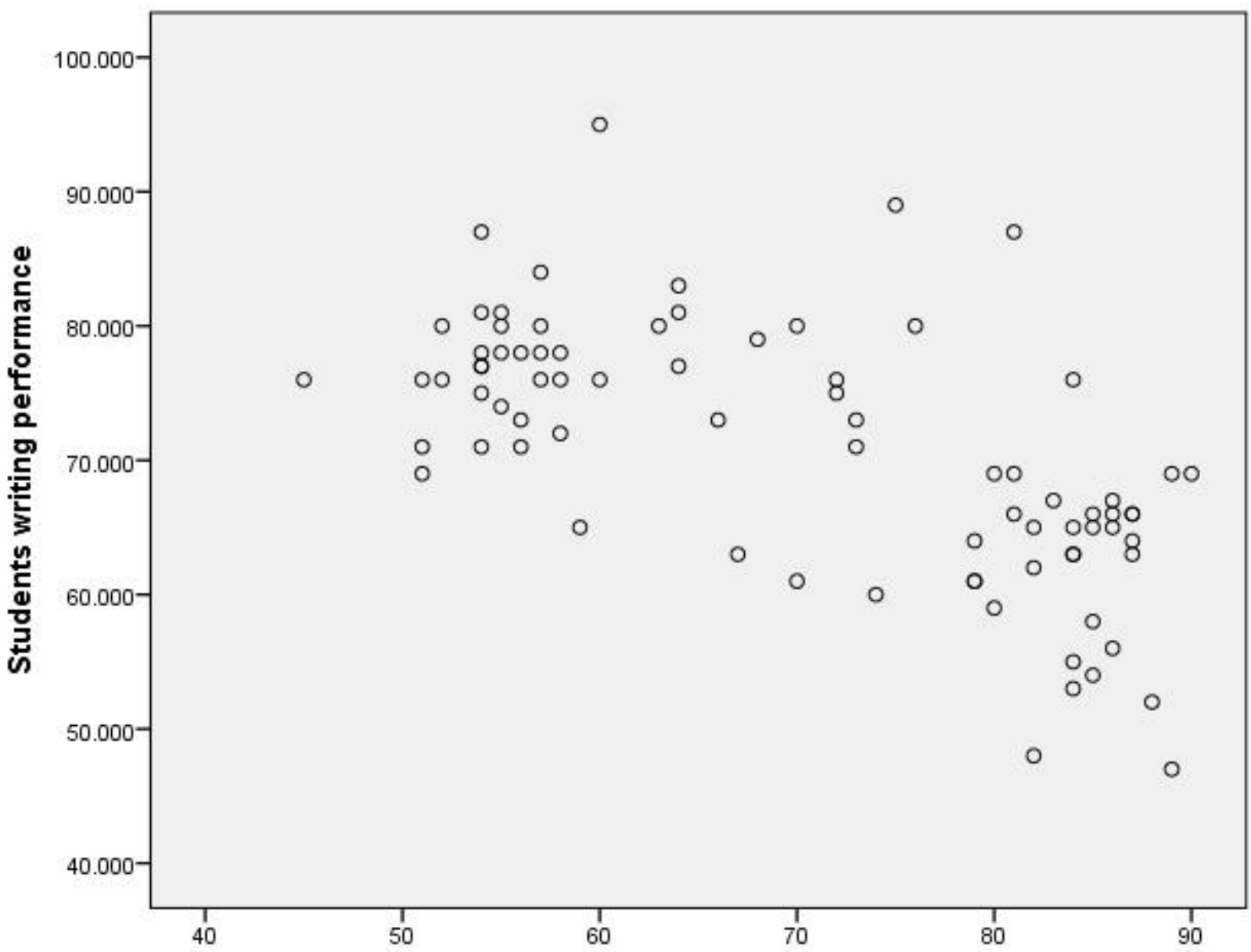

\section{SL/FL writing anxiety score}

Fig.1: The relationship between writing performance test scores and writing anxiety scores

Table 5: The relationship between writing performance and SLWAS

\begin{tabular}{llll}
\hline Variables & & Test score & $\begin{array}{l}\text { Second language writing } \\
\text { anxiety scale }\end{array}$ \\
\hline Students writing performance Test & Pearson correlation & 1.000 & $-.772^{* *}$ \\
score & Sig.(2-tailed) & & .000 \\
& $\mathrm{~N}$ & 80 & 80 \\
Second language writing anxiety & Pearson correlation & $-.772^{* *}$ & 1.000 \\
scale & Sig.(2-tailed) & 1.000 & \\
& $\mathrm{~N}$ & 80 & 80 \\
\hline
\end{tabular}

Note** Correlation is significant at the 0.01 level (2-tailed).

As Table 5 shows, there is a strong negative correlation between ESL writing performance test score and SL/FL writing anxiety with $\mathrm{r}=-.772 * *$ and $\mathrm{p}=.000<.01$. The negative correlation between the two variables (test score and writing anxiety score) indicate that as the students' Second language writing anxiety decreases, their writing performance increases. When students write English compositions under time constraint, they become stressed and anxious, this in turn influences the next content and activities of writing tasks. 
6.1.2 Causes of ESL Writing anxiety

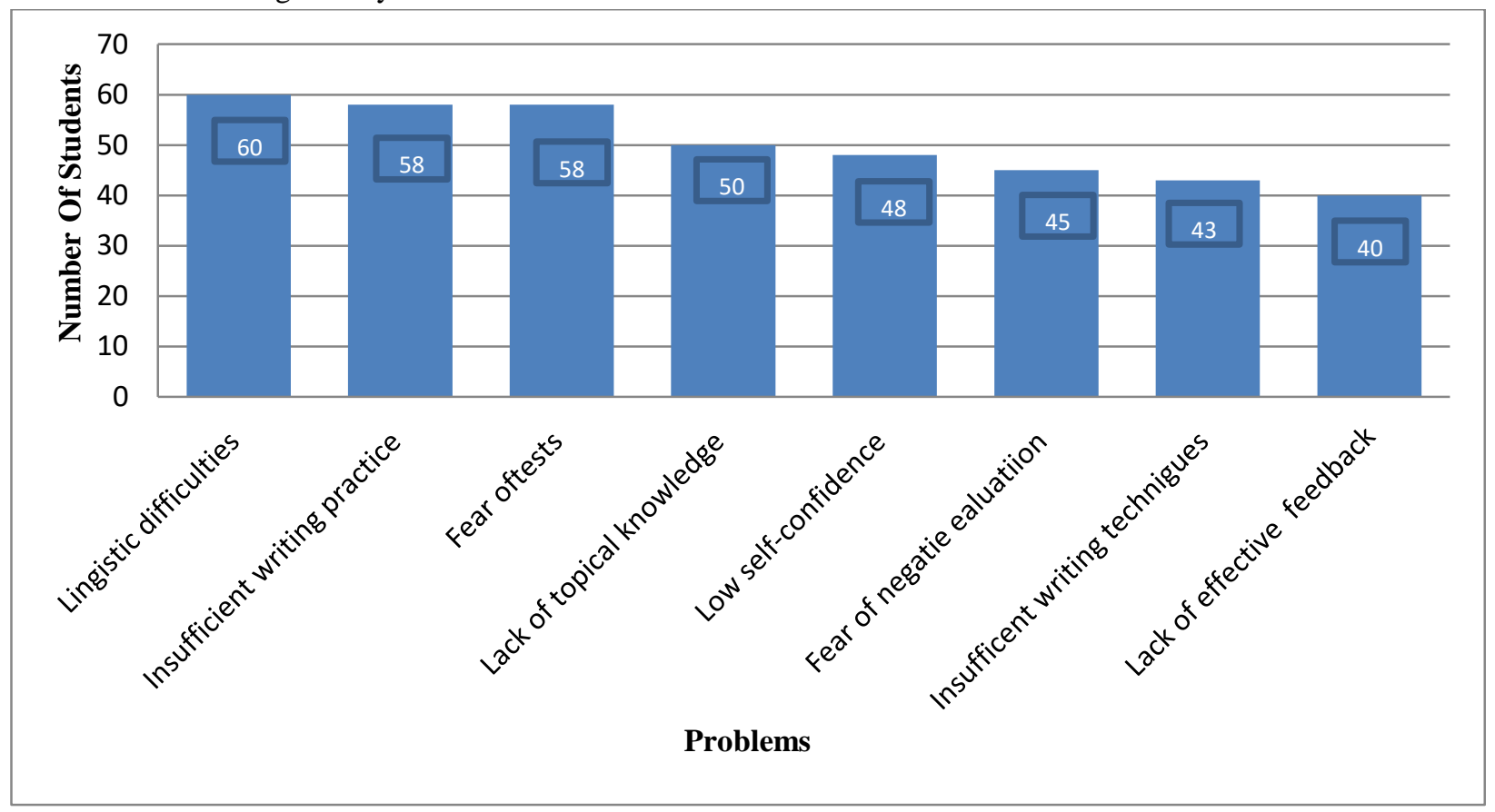

Fig.2: Causes of ESL writing anxiety

As can be seen in the figure above, the common sources of ESL writing anxiety is linguistic difficulties $60(75 \%)$ thought their English writing anxiety was from linguistic difficulties, such as inadequate mastery of vocabulary, simple sentence structures and grammatical errors. 58(73\%) students thought they lack writing practice inside and outside the classroom. $58(73 \%)$ of the students worried about writing English compositions in tests. 50 students(63\%) reported that they usually had no idea about the topic and what to write, in particular when writing English compositions under time constraint. 48 students $(60 \%)$ lack confidence in L2 writing achievement, which made them feel upset. 45 students (56\%) were afraid of negative evaluation from teacher and fellow students. 43 students (54\%) attributed L2 writing anxiety to insufficient writing techniques. 40 students (50\%) thought the teacher's feedback on their English composition was not adequate and effective, which made them anxious. The results of Questionnaire II showed that linguistic difficulties, insufficient writing practice, fear of tests, lack of topical knowledge and low self confidence in English writing performance are the most common causes of L2 writing and constitute the main sources of English writing anxiety in this study. $75 \%$ of the students thought their English writing stemmed from linguistic difficulties, such as inadequate mastery of vocabulary, simple sentence structures and grammatical errors.

6.1.2.1 Results of Semi-Structured Students Interview

Table 6: Contexts and Factors Causing Anxiety when writing in English

\begin{tabular}{|l|l|l|l|}
\hline Causes & HA & MA & LA \\
\hline Poor grammar knowledge & 4 & 3 & 1 \\
\hline Insufficient writing practice & 3 & 2 & 1 \\
\hline Inability to organize thoughts and ideas & 4 & 3 & 1 \\
\hline Fear of writing test & 3 & 2 & 2 \\
\hline Fear of teacher's negative evaluation & & & \\
\hline Lack of interest in writing & 2 & 2 & 1 \\
\hline Lack of sufficient time for writing practice & 3 & 2 & 2 \\
\hline
\end{tabular}


The data obtained from the interview showed that students, particularly in the HA group, found poor linguistic and writing abilities as the main sources of writing anxiety. In this regard, some students in the MA group mentioned: "I have lots of ideas to write about, but I'm not sure how to express them in English. My instructor believes that my writings are not interesting to see and read to him. I always have lots of grammatical errors and my writing is difficult to understand."

The students were also upset about writing tests and teacher's negative evaluation as reflected in the following statement by students in the HA group:

"I study hard before my writing exams and even prepare some writing exams, but as the exam starts, my mind goes absent, and I'm worry about getting a low score by the teacher. This makes me anxious."

Although most of the results obtained from the interview were in line with the data obtained from the CSLWAI, some areas of differences between the two were spotted. The students reported other sources of writing anxiety, namely lack of sufficient time for writing practice, and lack of interest in writing.

In general, the results of the semi-structured interview confirmed the data obtained from the CSLWAI. It was concluded that students suffer from nervousness as far as writing is concerned due to poor linguistic knowledge, fear of negative evaluation and writing exams along with time constraints and lack of motivation or interest in writing.

Table 7: one-Way ANOVA for Students Writing Test Achievement and SLWA levels

\begin{tabular}{llllll}
\hline Source of variation & Sum of squares & DF & Mean square & F & Sig \\
\hline Between Groups & 5017.477 & 2 & 2508.738 & 45.961 & .000 \\
& & & & & \\
Within Groups & 4203.011 & 77 & 54.585 & & \\
Total & 922.488 & & & & \\
\hline
\end{tabular}

The above table shows that the calculated value of $\mathrm{F}$ is 45.961 which is greater than the value table or critical value or 4.80 at $5 \%$ level with degree of freedom being variation Between Groups ( $\mathrm{V} 1=2$, and variation Within Groups ( V2=77 ). This means that the test score was significantly different for the three (low, average, and high) FLWA/SLWA levels (Sig.000).

However, in order to identify the significant differences among the pairs of L2/FL writing anxiety, multiple comparisons or a Post Hoc test was conducted in the following table.

Table 8: Differences among Writing Test achievement and SLWA levels

\begin{tabular}{|c|c|c|c|c|c|c|}
\hline \multirow[t]{3}{*}{$\begin{array}{l}\text { (I) second language } \\
\text { writing anxiety scale }\end{array}$} & \multirow[t]{3}{*}{$\begin{array}{l}\text { (J) second language } \\
\text { writing anxiety scale }\end{array}$} & \multirow[t]{3}{*}{$\begin{array}{l}\text { Mean Difference } \\
(\mathrm{I}-\mathrm{J})\end{array}$} & \multirow[t]{3}{*}{$\begin{array}{l}\text { Std. } \\
\text { Error }\end{array}$} & \multirow[t]{3}{*}{ Sig. } & \multicolumn{2}{|c|}{$\begin{array}{l}\text { 95\% Confidence } \\
\text { Interval }\end{array}$} \\
\hline & & & & & Lower & Upper \\
\hline & & & & & Bound & Bound \\
\hline \multirow[t]{2}{*}{ Low Anxiety level } & Average Anxiety level & $9.861^{*}$ & 4.084 & .018 & 1.73 & 17.99 \\
\hline & High Anxiety level & $25.233^{*}$ & 3.819 & .000 & 17.63 & 32.84 \\
\hline \multirow[t]{2}{*}{ Average Anxiety level } & Low Anxiety level & $-9.861^{*}$ & 4.084 & .018 & -17.99 & -1.73 \\
\hline & High Anxiety level & $15.372^{*}$ & 1.993 & .000 & 11.40 & 19.34 \\
\hline \multirow[t]{2}{*}{ High Anxiety level } & Low Anxiety level & $-25.233^{*}$ & 3.819 & .000 & -32.84 & -17.63 \\
\hline & Average Anxiety level & $-15.372^{*}$ & 1.993 & .000 & -19.34 & -11.40 \\
\hline
\end{tabular}

Note* the mean difference is significant at the 0.05 level.

The multiple comparisons or ANOVA Table shows that the mean differences are significant between the low anxiety and average anxiety (9.861, sig. =.o18), low anxiety and high anxiety $(25.233$, sig. $=.000)$, and average anxiety and high anxiety (15.372, sig. $=.000)$.
These results indicated that there was a moderate mean difference between low and average anxious students, but the difference was a little bit bigger for average and high anxious students than the low and average anxious students. 


\subsubsection{Effect of ESL Writing Anxiety on Writing Performance}

(SLWAI Questionnaire Results in terms of ESL/FL writing anxiety)

It should be pointed out that ESL writing anxiety can have many negative effects, for instance, on learners' behavior; it may cause physical symptoms. Referring to the results of Questionnaire I, most students reported that they experienced avoiding writing English compositions or avoiding situations that require writing in English. It is widely acknowledged that writing is a productive activity and needs a certain quantity of practice.

Avoidance behavior, as a result of ESL/FL writing anxiety, would in turn be harmful to second language writing improvement and cause higher anxiety. Some students told physical effects of writing anxiety. The present study found that the seriousness of anxiety was very high with fear of avoidance behavior and cognitive anxiety which was close to 4.0.

Thus, the results of this study revealed a fact that students were highly anxious, as a result of ESL writing anxiety, would in turn be harmful to L2 writing improvement and cause higher anxiety.

\subsubsection{The Nature of Writing Anxiety}

In this section, it is aimed to indicate how anxious students were in performing writing activities.

The theoretical score range of this scale was from 45 to 90 . The ideal mean score is expected to be $67.5(45+90) / 2$. Therefore, the following table shows the general anxiety condition of the learners.

Table 9: General Anxiety situation of Respondents/ Students

\begin{tabular}{|l|l|l|}
\hline Anxiety level of the participants & № of students & Percentage \\
\hline Anxiety level of participants above 65 & 58 & 72.5 \\
\hline Anxiety level of participants in between 50 and 65 & 18 & 22.5 \\
\hline Anxiety level of participants below 50 & 4 & 5 \\
\hline Total & 80 & 100 \\
\hline
\end{tabular}

Table 9 reveals that from the total of 80 students or subjects of the study, 58(72.5\%) scored anxiety level above the ideal mean score. This suggests that subjects are highly anxious to write as second or foreign language. Of the 80 students, only 4(5\%) experienced low levels of EFL or ESL writing anxiety. Highly anxious students were even more than twice of average level of anxious students. Similarly, question (1) of semi-structured interview conducted with students was aimed to extract the degree and effects of writing anxiety of ESL learners and accordingly, students expressed that "I have lots of ideas to write about, but I'm not sure how to express them in English. My instructor believes that my writings are not English. I always have lots of grammatical errors and my writing is difficult to understand. Above all, many students besides me are not willing to participate in writing activities, for example, writing a paragraph, narrative and descriptive compositions and like, these are communication apprehension, test anxiety, fear of negative evaluation, which are the sign of anxious students" (student1). In addition, question (3) of interview conducted with students was also intended to investigate whether their learning English as second or foreign language causes writing anxiety in classroom or not. Almost all students underlined that writing anxiety significantly affects the learning process of writing in ESL classroom. Writing class was not interesting for them because they are not eager to participate in activities. They expressed that their earlier high school learning practice was the main sources for the failure or the passive participation of students to use the target language in classroom"(student2).

From the above data gathered from students through interview, one can infer that writing anxiety is a serious issue that influences the teaching learning process of ESL/FL in the University under the study.

\subsubsection{Level of Anxiety within Variables}

(Zhang's, 2011 Model Table of SLWAI Variables)

The section also identified the dominant type of writing anxiety that the subjects of this study experienced.

Table 10: The level of Anxiety within variables

\begin{tabular}{|l|l|l|}
\hline Anxiety variables & № of Items & Mean \\
\hline Cognitive Anxiety & 8 & 28 \\
\cline { 3 - 3 } & & 3.50 \\
\hline
\end{tabular}




\begin{tabular}{|l|l|l|}
\hline Somatic Anxiety & 7 & 18.30 \\
\cline { 3 - 3 } & & 2.61 \\
\hline Avoidance Behavior & 7 & 26 \\
\cline { 3 - 3 } & & 3.71 \\
\hline Total & 22 & 72.30 \\
\cline { 3 - 3 } & & 3.29 \\
\hline
\end{tabular}

Table 10 indicates that all anxiety variables such as cognitive anxiety, somatic anxiety and avoidance behavior were 3.50 , 2.61 and 3.71 respectively. The results indicated the seriousness of anxiety in the College. The seriousness of anxiety was high with fear of avoidance behavior and cognitive anxiety which was above the mean score 3.00.

These results might occur, for example, according to Horwitz, et al (1986), students with average around 3.00 should be considered slightly anxious, while students with average below 3.00 are probably not anxious; students whose average nears to four are probably fairly anxious.

\subsection{Cognitive Anxiety}

This part reports the result obtained from the first category of the SLWAI labeled as cognitive anxiety which deals with negative expectation, fear or worry of negative evaluation and tests.

Table 11: Anxiety scales Related to Cognitive Anxiety

(Zhang's Model Table to SLWAI Variables, 2011: 23)

\begin{tabular}{|c|c|c|c|c|c|c|}
\hline Items & Questions & Scales & $\begin{array}{l}\text { № of } \\
\text { students }\end{array}$ & $\sum f x$ & $\%$ & Mean $=\sum f x / \sum$ \\
\hline \multirow[t]{5}{*}{1} & \multirow{5}{*}{$\begin{array}{l}\text { While writing in English, I'm } \\
\text { Not nervous at all }\end{array}$} & SA & 41 & 205 & 51.3 & \multirow{5}{*}{4.39} \\
\hline & & A & 32 & 128 & 40 & \\
\hline & & UN & 4 & 12 & 5 & \\
\hline & & $\mathrm{D}$ & 3 & 6 & 3.8 & \\
\hline & & SD & 0 & 0 & 0 & \\
\hline \multirow[t]{5}{*}{2} & \multirow{5}{*}{$\begin{array}{l}\text { While writing English } \\
\text { Compositions, I fee worried } \\
\text { and uneasy if I know they will } \\
\text { be evaluated. }\end{array}$} & SA & 11 & 55 & 13.8 & \multirow{5}{*}{2.79} \\
\hline & & $\mathrm{A}$ & 18 & 72 & 22.5 & \\
\hline & & UN & 12 & 36 & 15 & \\
\hline & & $\mathrm{D}$ & 21 & 42 & 26.3 & \\
\hline & & SD & 18 & 18 & 22.5 & \\
\hline \multirow[t]{5}{*}{3} & \multirow{5}{*}{$\begin{array}{l}\text { I don't worry that my English } \\
\text { compositions are a lot worse } \\
\text { than others'. }\end{array}$} & SA & 41 & 205 & 51.2 & \multirow{5}{*}{4.2} \\
\hline & & $\mathrm{A}$ & 25 & 100 & 31.3 & \\
\hline & & UN & 5 & 15 & 6.3 & \\
\hline & & $\mathrm{D}$ & 7 & 14 & 8.8 & \\
\hline & & SD & 2 & 2 & 2.5 & \\
\hline \multirow[t]{5}{*}{4} & \multirow{5}{*}{$\begin{array}{l}\text { If my English } \\
\text { Composition is to be } \\
\text { evaluated; I would worry } \\
\text { about getting a very poor } \\
\text { grade. }\end{array}$} & SA & 10 & 50 & 12.5 & \multirow{5}{*}{2.64} \\
\hline & & $\mathrm{A}$ & 17 & 68 & 21.3 & \\
\hline & & UN & 9 & 27 & 11.3 & \\
\hline & & $\mathrm{D}$ & 22 & 44 & 27.5 & \\
\hline & & SD & 22 & 22 & 27.5 & \\
\hline
\end{tabular}

As can be seen from Table 11, question (1), 73(91\%) agreed or strongly agreed with it. It is evident from the scores most students seem to suffer from cognitive anxiety.
Consequently, students' face of cognitive anxiety influences them from active participation of writing activities. 


\subsection{Somatic Anxiety}

This part reports the result obtained from second category of the SLWAI labeled as somatic anxiety which is defined as an individual perception of the physiological effects of the anxiety experience, as reflected in increase in state of unpleasant feelings, such as nervousness and tension (Cheng, 2004: 316). The scores of the responses are illustrated in the following table.

Table 12: Anxiety scales Related to Somatic Anxiety

(Zhang's Model Table to SLWAI Variables, 2011:23)

\begin{tabular}{|c|c|c|c|c|c|c|}
\hline Items & Questions & Scales & № of students & $\sum f x$ & $\%$ & Mea $=\sum f x / \sum f$ \\
\hline \multirow[t]{5}{*}{1} & \multirow{5}{*}{$\begin{array}{l}\text { I feel my heart pounding when } \\
\text { I write English compositions } \\
\text { under time constraint. }\end{array}$} & SA & 12 & 60 & 15 & \multirow{5}{*}{3.34} \\
\hline & & $\mathrm{A}$ & 29 & 116 & 36.3 & \\
\hline & & UN & 19 & 57 & 23.8 & \\
\hline & & $\mathrm{D}$ & 14 & 28 & 17.5 & \\
\hline & & SD & 6 & 6 & 7.5 & \\
\hline \multirow[t]{5}{*}{2} & \multirow{5}{*}{$\begin{array}{l}\text { My mind often goes blank } \\
\text { when I start to work on an } \\
\text { English composition. }\end{array}$} & SA & 4 & 20 & 5 & \multirow{5}{*}{1.91} \\
\hline & & A & 6 & 24 & 7.5 & \\
\hline & & UN & 8 & 24 & 10 & \\
\hline & & $\mathrm{D}$ & 23 & 46 & 28.8 & \\
\hline & & SD & 39 & 39 & 48.8 & \\
\hline \multirow[t]{5}{*}{3} & \multirow{5}{*}{$\begin{array}{l}\text { I tremble or perspire when I } \\
\text { write English compositions } \\
\text { under time pressure. }\end{array}$} & SA & 9 & 45 & 51.2 & \multirow{4}{*}{2.38} \\
\hline & & A & 9 & 36 & 31.3 & \\
\hline & & UN & 9 & 27 & 6.3 & \\
\hline & & $\mathrm{D}$ & 29 & 58 & 8.8 & \\
\hline & & SD & 24 & 24 & 2.5 & \\
\hline \multirow[t]{5}{*}{4} & If my English & SA & 6 & 30 & 12.5 & \\
\hline & \multirow{4}{*}{$\begin{array}{l}\text { Composition is to be evaluated; } \\
\text { I would worry about getting a } \\
\text { very poor grade. }\end{array}$} & A & 24 & 96 & 21.3 & \multirow{4}{*}{2.96} \\
\hline & & UN & 19 & 57 & 11.3 & \\
\hline & & $\mathrm{D}$ & 23 & 46 & 27.5 & \\
\hline & & SD & 8 & 8 & 27.5 & \\
\hline
\end{tabular}

As can be seen from Table 12, a large number of respondents agreed or strongly agreed that writing in time constraints causes tremble to write English compositions. Among 80 students of the study, 41(51\%) of them strongly agreed or agreed that writing English compositions under time constraint feel heart pounding to write. Most of the foreign scholars or researchers complained that nervousness of ESL/FL students for writing classroom was major problems that impede or hinder their writing skill and language learning. They stated that most ESL/FL learners do not get ready rather they are confused to write a single sentence. As result, ESL/FL teachers feel bored with writing lessons and sometimes tend to teach other language skills (Zhang, 2011).

\subsection{Avoidance Behavior}

This theme presents the result concerning learners' behavior. Referring to the results of Questionnaire, most students reported that they experienced avoiding writing English compositions or avoiding situations that require writing in English. Avoidance Behavior refers to the behavioral aspect of the anxiety experience, avoidance of writing (Cheng, 2004:316). It is widely acknowledged that writing is a productive activity and needs a certain quantity of practice. Avoidance behavior, as a result of ESL/FL writing anxiety, would in turn be harmful to L2 writing improvement and cause higher anxiety. Some students reported physical effects of writing anxiety. They experienced various symptoms of anxiety more or less, such as accelerated heart beat, perspiration and shyness. 
Table 13: Anxiety scales Related to Avoidance Behavior

(Zhang's Model Table to SLWAI Variables, 2011: 23)

\begin{tabular}{|c|c|c|c|c|c|c|}
\hline Items & Questions & Scales & $\begin{array}{l}\text { № of } \\
\text { students }\end{array}$ & $\sum f x$ & $\%$ & Mea $=\sum f x / \sum f$ \\
\hline \multirow[t]{5}{*}{1} & \multirow{5}{*}{$\begin{array}{l}\text { I often choose to write down } \\
\text { my thoughts in English. }\end{array}$} & SA & 3 & 15 & 3.8 & \multirow{5}{*}{2.05} \\
\hline & & $\mathrm{A}$ & 13 & 52 & 16.3 & \\
\hline & & UN & 6 & 18 & 7.5 & \\
\hline & & $\mathrm{D}$ & 21 & 42 & 26.3 & \\
\hline & & SD & 37 & 37 & 46.3 & \\
\hline \multirow[t]{5}{*}{2} & \multirow{5}{*}{$\begin{array}{l}\text { I usually do my best to avoid } \\
\text { writing English compositions. }\end{array}$} & SA & 28 & 140 & 35 & \multirow{5}{*}{3.53} \\
\hline & & A & 20 & 80 & 25 & \\
\hline & & UN & 10 & 30 & 12.5 & \\
\hline & & $\mathrm{D}$ & 10 & 20 & 12.5 & \\
\hline & & SD & 12 & 12 & 15 & \\
\hline \multirow[t]{5}{*}{3} & \multirow{5}{*}{$\begin{array}{l}\text { I do my best to avoid situations } \\
\text { in which I have to write in } \\
\text { English. }\end{array}$} & SA & 56 & 280 & 70 & \multirow{5}{*}{4.33} \\
\hline & & $\mathrm{A}$ & 11 & 44 & 13.8 & \\
\hline & & UN & 1 & 3 & 1.2 & \\
\hline & & $\mathrm{D}$ & 7 & 14 & 8.8 & \\
\hline & & SD & 5 & 5 & 6.3 & \\
\hline \multirow[t]{5}{*}{4} & \multirow{5}{*}{$\begin{array}{l}\text { Unless I have no choice, I } \\
\text { would not use English to write } \\
\text { composition. }\end{array}$} & SA & 40 & 200 & 50 & \multirow{5}{*}{3.91} \\
\hline & & $\mathrm{A}$ & 13 & 52 & 16.3 & \\
\hline & & UN & 12 & 36 & 15 & \\
\hline & & $\mathrm{D}$ & 10 & 20 & 12.5 & \\
\hline & & SD & 5 & 5 & 6.3 & \\
\hline
\end{tabular}

As can be seen from Table 13, a large number of respondents strongly disagree or disagree learners' avoidance behavior while learning to write English. For example, among 80 subjects or students of the study $48(60 \%)$ strongly agree or agree that do their best to avoid writing English compositions. It is evident from the scores most students seem to do their best to avoid situations in which they have to write in English.

\section{DISCUSSION}

The research questions were discussed and interpreted as follows.

1. Is there significant correlation between English writing anxiety and students' writing performance?

The correlations appeared in Table 5 showed a score( $\mathrm{r}=$ 0.772) or It means students who experienced higher writing anxiety received lower course grade or performance test scores with $\mathrm{r}=-0.772 * *$ and $\mathrm{p}=.000<.01$. The negative correlation between the two variables (writing test scores and writing anxiety scale scores) indicate that as the students' foreign or second language writing anxiety increases, their writing performance decreases. This study result was consistent with and supported the earlier researchers who found that high anxiety is related negatively to classroom performance and foreign or second language writing or listening comprehension performance (Cheng et al., 1999, Cheng, 2004, Abate, 1996; Belilew \& Garoma, 2017).

The comparison of performances of high, average and low anxious learners revealed the presence of significant differences. These findings are consistent with both foreign researches and local researches which indicated a low anxiety level to be related with better performance (Zhang, 2011; Dulay et al., 1982; Brown, 1987; Larsen Freeman \& Long, 1991; MacIntyre \& Gardner, 1994 cited in Abate, 1996, Belilew \& Garoma, 2017).

2. What do the students identify as the sources of their English writing anxiety?

The results of Questionnaire II showed that linguistic difficulties, insufficient writing practice, fear of tests, lack of topical knowledge and low self- confidence in English writing performance are the most common causes of L2 writing anxiety. In addition to mentioned results, students' 
semi-structured interview revealed that students suffered from nervousness as far as writing is concerned due to poor linguistic knowledge, fear of negative evaluation and writing exams along with time constraints, and lack of motivation or interest in English writing. The result was consistent with the study of Hyland (2003:34, cited in Zhang, 2011) which claimed that most immediately obvious factor that distinguished EFL/ESL writers is the difficulty they have inadequately expressing themselves in English. 63\% of the students reported that they usually had no idea about the topic and what to write, in particular when writing English compositions under time constraint.

Many foreign researchers about foreign or second language writing anxiety pointed out that time, topic and language might be important factors of poor EFL/ESL writing as well as writing anxiety (Hyland, 2003; Leki \& Carson, 1997). For instance, Hyland cited Leki and Carson's (1997) EFL/ESL students' statement on their experience in L2 writing (Hyland, 2003:41).

Almost all learners would be too concerned about linguistic components when writing in English, such as sentence structure, grammar rules and correct spelling, as accuracy is always regarded as the principal objective for FL/L2 teaching and learning, for evaluation. Thus, students' self-perception of linguistic difficulties turned out to be the most important reason for writing anxiety.

3. Is there statistically significant difference in level of anxiety among low, average and high achievers?

The relation between FL or ESL writing anxiety and the students' writing performance and their statistical analysis indicated that at $5 \%$ level of significance $(\mathrm{p}=000<0.05)$ has a significant difference in level of anxiety among low, average and high achievers. This means that the test scores were significantly different for the three levels (low, average and high) FL or L2 writing anxiety levels $(\mathrm{p}=000)$. The results found were consistent with earlier findings in that low-anxious language learners tended to perform better than those with higher anxiety scores. For example, among students with high, average and low levels of anxiety showed that students with low levels of anxiety performed consistently higher on measures of English achievement (Sanchez, 1992; cited in Abate, 1996).

4. What is the dominant type of writing anxiety the students' experience?

The result revealed a fact that students highly pressured of tests and evaluation in EFL writing that is similar to the findings in this study which fears of test and negative evaluation were the main factors associated with ESL/EFL writing anxiety (see Fig.2), and supports Zhang's conclusion (2011:29) that cognitive anxiety related closely to test anxiety and could have a great influence in L2 or EFL writing performance. The second dominant type of EFL writing anxiety experienced by the subjects' of this study was Avoidance Behavior. Avoidance Behavior refers to the behavioral aspect of the anxiety experience, avoidance of writing (Cheng, 2004:316). Besides, the subjects of this study in their self responded SLWAI questionnaire 48(60\%) responded "strongly agreed or agreed" when answering the item " I usually do my best to avoid writing English compositions, " $67(84 \%)$ students chose " strongly agree or agree " in the item "I do my best to avoid situations in which I have to write in English ". The results were consistent with the previous foreign or second language researchers' findings. For instance, the results of Zhang's (2011), showed that cognitive anxiety is the most common and dominant type of ESL writing anxiety experienced by Chinese English majors. Thus, the result revealed a fact that subjects of this study reported that they experience avoiding writing English compositions or avoiding situations that require writing in English

\section{CONCLUSIONS AND RECOMMENDATIONS}

This chapter presents the conclusions and recommendations based on the findings for alleviating EFL writing anxiety and to make writing class interesting.

\subsection{Conclusions}

With the respect to the differences in the level of anxiety among low, average and high achiever students, the study found that the majority of the students experience high level of anxiety. Because of this, they were weak or poor in their writing test performance. However, average anxious students were better than high anxious students but low anxious students were better than both average and high anxious students in their writing performance test. Second, there were some negative effects of ESL writing anxiety on the ESL writing performance, such as avoiding writing English compositions or avoiding situations that require writing in English. For instance, physical symptoms such as heart beat perspiration. Third, some sources of students' writing anxiety were linguistic difficulties, insufficient writing practice, fear of test, lack of topical knowledge, low self confidence in writing performance and these may lead them to poor performance and negative assumption about the target subject. These sources of students writing anxiety were also confirmed by students' interview. Finally, among three types of ESL/FL writing anxiety, the avoidance behavior and 
cognitive anxiety were the most common and dominant type of anxiety which students' of this study experience.

\subsection{Recommendations:}

Based on the findings of the study, the researcher forwarded the following recommendations.

\subsubsection{Recommendation for Students:}

Since ESL writing anxiety and students' writing performance were negatively related, anxious students could not have most probably confidence in their writing performance. Therefore, students should be given sense of confidence, encouraged to do writing activities, enabled to apply technique that minimize ESL writing anxiety.

\section{3.2 Recommendation for Teachers/ Instructors}

As the avoidance behavior or factors, such as physical symptoms, heart beat and shyness have significant effect on the ESL students 'writing performance, ESL teachers or instructors should make writing classroom and teaching approaches attractive and give autonomy for the students.

Since there is statistically significant difference among students in writing performance and anxiety level, teachers or instructors need to mix students with different performance level. Lack of motivation and interest in writing course is lack of ownership so that ESL teachers or instructors should increase students' ownership of the importance of writing.

The main sources of ESL writing anxiety in this study revealed a number of factors which were identified as the main sources of ESL writing anxiety were like: linguistic difficulties, fear of test, insufficient writing practice, lack of topical knowledge and low self- confidence in writing performance. Therefore, teachers or instructors of ESL writing should acknowledge these factors of ESL writing anxiety at first and then they should help students to bring affective strategies to ESL writing tasks which can greatly facilitate the learners' development.

\subsubsection{Recommendation for Course Material Designers or Testers:}

Testers and course book or text book designers should think of a variety of different strategies that could help to alleviate the anxiety learners might experience in the ESL writing classroom and incorporate them in the tests they develop and the text books or course materials they use.

Furthermore, concerned bodies also should give trainings to instructors and ESL teachers regarding teaching writing skill/ course.

\section{REFERENCES}

[1] Abate Kassahun. (1996). 'English Language Classroom Anxiety, Performance on classroom Tasks and Tests: A study of some Ethiopian Civil Service College 1 year Students.' Addis Ababa: AAU (M.A Thesis, un published).

[2] Aida, Y. (1994). Examination of Horwitz and Cope's construct of foreign language anxiety. The case of students of Japanese. The Modern Language Journal, 78,155-168.

[3] Alamirew G/ Mariam. (2005). A study on the Perception of Writing, Writing Instruction and students' writing performance. UN published Ph.D Dissertation, Addis Ababa University School of Graduate Studies, Addis Ababa.

[4] Amlaku Eshetie. (2013). Language Policies and the Role of English in Ethiopia 1, https: / www. Research gate.net/ publication/ 259267200. KHAABBA International Training and Language Service.

[5] Bailey, P., Daley, C.E., \& Onwuegbuzie , A.J. (1999). Foreign language anxiety and learning Applied Psycholinguistics, 20,217-239.

[6] Belilew Molla \& Garoma Tesisa .( 2017 ). Relationship between Foreign Language Listening Anxiety and Listening Comprehension. Journal of Language Learning. URL: http: $/ / \mathrm{mc}$.manuscript central.com/rllj.

[7] C. Harmer, J. (2007). How to teach Writing to Second Language Learners

[8] Cheng, Y., Horwitz, E.K., \& Schallert, D.L. (1999). Language anxiety: Differentiating writing and speaking components. Language Learning, 49(\#), 417-446

[9] Cheng, Y.S. (2002). A measure of second language writing anxiety: scale development and preliminary validation. Journal of second language writing, 13(4), 313-335.

[10] Cheng, Y-S (2004). A measure of second language writing anxiety: Scale development and preliminary validation. Journal of second Language writing 13,313-335

[11] Cheng, Y-S. (2002). Factors associated with foreign language writing anxiety. Foreign language Annals, 35,647-656.

[12] CHOI, S. (2013). 31(2): Language Anxiety in Second Language Writing: University of Hawai; at Manoa

[13] Cohen, Y., Horwitz, E.K., \&Schaller, D.L. (1998). Fear, dependence, and Loss of self-esteem: affective barriers in among adults. RELC journal 20, 61, 77.

[14] Creswell, JW. (2008). Research Design: Qual, Quant, and Mixed Methods Approaches. $3^{\text {rd }}$ edition. SAGE Publication .USA.

[15] Dagnachew Terefe (2013). Investigating Writing Anxiety of Grade 11 students and its effects on their writing skill: The case of Boditi Preparatory school, Wolaita Zone

[16] Daly, J., \& Witte, S.P. (1981). The role of writing apprehension in writing performance and competence. Journal of Educational Research, 72(1), 16-21. Retrieved from http://www. Jstor. Org/ stable / 27539858

[17] Doornyei.Z. (2007). Research Methods in Applied Linguistics. Oxford University Press.

[18] Gregersen, T.S. \&Hurwitz, E.K. (2002). Language learning and perfectionism: anxious and non- anxious language 
learners' reactions to their own oral performance. The modern language Journal, 86(3), 562-570.

[19] Hartono, H. (2012). The Correlation between students' Level of Anxiety and students' Achievement in Writing.

[20] Hassan, B. (2001). The Relationship of Writing Apprehension and self-Esteem to the writing Quality and Quantity of EFL University Student. Mansoura Faculty of Education Journal, 39, 1-36.

[21] Horwitz, E., K. (1986). Preliminary evidence for the reliability and validity of a foreign language anxiety scale. TESOL Quarterly, 20,559-562

[22] Horwitz , E.K. Horwitz , M.B \& Cope, J ( 1986). Foreign language classroom anxiety. The modern language journal, 70,125-132.

[23] Horwitz, E.K.(2001). Language anxiety and achievement. Annual Review of applied linguistics 21,112-126. Doi: 10.1017/S0267190501000071

[24] Italo Beriso. (1999). "A comparison of the effectiveness of Teacher versus Peer feedback on AAU students' Writing Revisions." (PhD Dissertation, Addis Ababa University).

[25] Krashen, S.D. (1982). Principles and practice in second language acquision. Pergamon press.

[26] Kurt, G \& Atay, D. (2007). The effect of peer feedback on the writing anxiety of prospective Turkish teachers of EFL, Journal of Theory and practice in Education, 3(1), 12-23.

[27] MacIntyre , P.D. , \& Gardner , R.C.( 1989). Anxiety and second language learning: Toward a theoretical clarification. Language Learning, 39,251-275.

[28] MacIntyre , P.D.., (1995). How does anxiety affect second language learning? A reply to sparks and Ganschow. The modern language journal, 79(1), 90-99

[29] MacIntyre, P.D and charos, C. (1991a). Methods and results in the study of anxiety using the focused essay technique. The modern language Journal, 75,296-304.

[30] MacIntyre, P.D and Gardner, R.C. (1991b). Investigating language class anxiety. Unpublished doctoral dissertation, catholic university of America, Washington, D.C

[31] MacIntyre, P.D. \& Gardner, R.C. (1991). Methods and results in the study of anxiety and language learning: A review of the literature. Language learning, 4, 85-117

[32] McMillan,J.H. and Schumacher,S(1997). Research in Education: A conceptual introduction. New York: Longman.

[33] Melesse Mitiku. (2007). 'An Assessment of English Language Writing Test Anxiety: The case of Two Private University College students Taking Sophomore English Writing Course' Addis Ababa: AAU. (MA Thesis Unpublished).

[34] Nakamura yuji(2004). A comparison of holistic and analytic scoring methods in the assessment of writing. Retrieved March 30, 2009, from http/ jalt org/ pansig/ 2004/ HTTML Nakamura htm

[35] Negari, G.M. and Rezaabadi, O.T. (2012). The relationship between anxiety and EFL writing. Theory and practice in Language studies. 2(12). 2578-2586.
[36] Nunan, D. (1995). Language teaching methodology: A text book for teachers. Hert fordshire:phoenix ELT.

[37] Oxford, R. L. (1999). Anxiety and the language learner: new insights. In J. Arnold (Ed.), Affect in Language learning (pp.58-67). Cambridge: Cambridge University Press.

[38] Richards and Rodgers. (2001). Approaches and Methods in Language Teaching: Cambridge University Press.

[39] Saito Y. and samimy. K (1996). Foreign language anxiety and language performance: annals a study of learner anxiety in beginning intermediate and advanced- level college students of Japanese. Foreign language Annals, 29,239-251.

[40] Spielberger (Ed). Anxiety and behavior. New York: academic press.

[41] Spielberger, C.D. (1966). Theory and research on anxiety. In C.D.

[42] Worwitz. E.K. Horwitz, M.B., \& Cope, J. (1986). Foreign language classroom anxiety. The modern language Journal. 70.125-132.

[43] Young, D.J. (1986). The relationship between anxiety and foreign language oral proficiency ratings. Foreign Language Annals, 19, 439-445.

[44] Zhang, H.X. (2011). A study on ESL writing anxiety among Chinese English majors - Causes effects and coping strategies for ESL writing anxiety. Retrieved on 25 August 2014 from http/www.divaportal.org/smash/get/diva2:426646/FULLTEXT 02. 